\title{
Mining
}

http://dx.doi.org/10.1590/0370-44672019730057

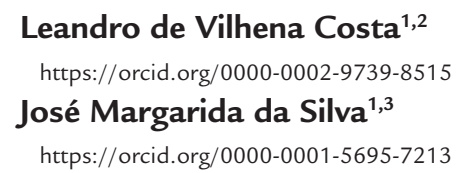

${ }^{1}$ Universidade Federal de Ouro Preto - UFOP, Escola de Minas, Departamento de Engenharia de Minas, Ouro Preto - Minas Gerais - Brasil.

E-mails: ${ }^{2}$ minas.leandro@gmail.com, 3josemargarida.silva@gmail.com

\section{Strategies used to control the costs of underground ventilation in some Brazilian mines}

\begin{abstract}
In an underground mine, the ventilation is responsible for $25 \%$ to $50 \%$ of its electrical energy consumption. In countries such as South Africa, United States and Canada researchers have started to achieve a significant reduction in energy consumption without neglecting aspects of the quantity and quality of air required for the best performance of the system, in compliance with safety standards and worker comfort. In Brazil, on demand this ventilation application began in 2013 at the Ipueira mine (Bahia, controlled by Ferbasa company), and was soon after applied by the Cuiabá, Córrego do Sitio I and Lamego mines; all three mines administered by Anglo Gold Ashanti. Each mine adopted frequency inverters for the main ventilation, whereby the fan rotation is adjusted according to demand and speed drivers. This measure resulted in the saving of thousands of reais, since the flow is proportional to the velocity, the pressure is proportional to the square of the velocity, and the power is proportional to the cubed velocity. Therefore, a reduction of $20 \%$ in the flow will save about $50 \%$ of the energy required. The Cuiabá mine presents the most modern and automated system in the country. The fans are controlled and monitored through a control room. In addition, sensors scattered in the mine, control the required flow rate. The Lamego mine has a similar but simpler system. This article proposes to discuss the application and improvement of the process of ventilation on demand in Brazilian mines where this system is applied.
\end{abstract}

keywords: ventilation on demand; underground mine; system of ventilation; energetic efficiency; energy consumption. the safety standards and comfort of the workers imposed by the inspection bodies.

Traditional ventilation systems tend to operate at their maximum capacity, operating 24 hours a day, necessary to maintain the required air supply, which for safety reasons are usually calculated based on the most pessimistic scenario possible. Such measure is probably unsustainable. Often the actual demand varies and may be much lower than the design capability. At times, when companies work with more scarce resources, there is a constant need to reduce costs due to increased energy consumption and consumption in recent years.

The VOD technology (Ventilation on Demand) provides airflow to an area, according to the amount of people and equipment present. This allows for a more efficient management of available airflow and compliance with standards without increasing ventilation costs. In this way, the areas being worked benefit from better and more efficient ventilation, while areas that are not being worked on are not ventilated. Overall, this leads to significant savings in electricity and other cost sources, making the mine much safer and more productive. Figure 1 shows a simplified ventilation system on demand, with the fans switched off at a certain time and connected only when it has personnel working or machinery in operation. 


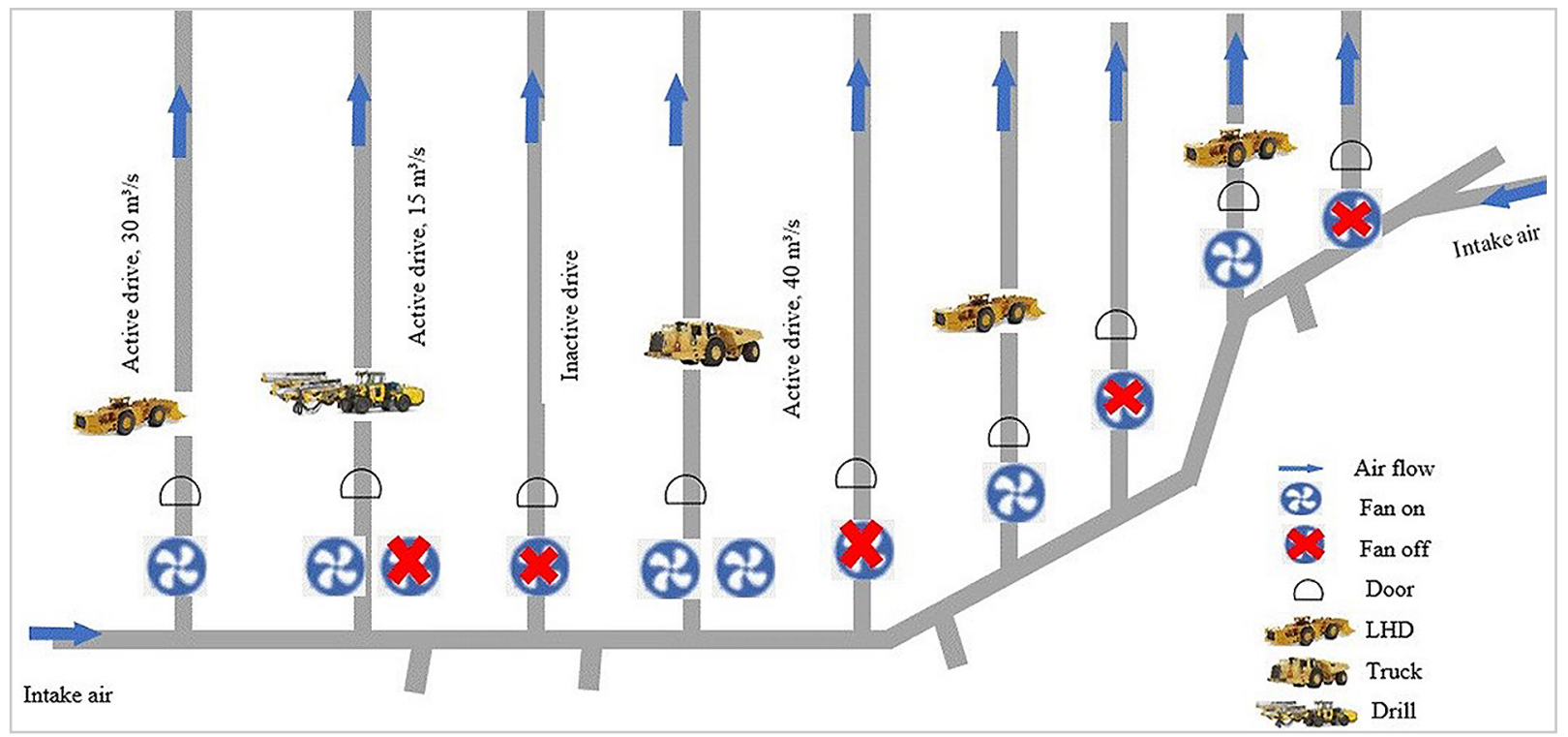

Figure 1 - Demand for ventilation fans setup showing connected and disconnected points (Costa, 2019).

By reducing total airflow, energy can be significantly saved due to the cubic relationship between airflow $\left(\mathrm{V}^{\prime}\right)$ and fan power $(\mathrm{P})$, as shown in the ex- pressions below ( $R$ is resistance; $\Delta p$ is the pressure difference):

$$
\mathrm{P}=\Delta \mathrm{P} \cdot \mathrm{V}^{\prime} \text { and } \Delta \mathrm{P}=\mathrm{R} \cdot \mathrm{V}^{\prime 2} \text {, resulting } \mathrm{P}=\mathrm{R} \cdot \mathrm{V}^{13}
$$

Using VOD with intelligent air management, it is possible that no additional volume is required. On average, ventilation accounts for up to $50 \%$ of a mine's energy costs and up to $15 \%$ of a mine's total costs. Thus, VOD may contain immense potential savings.

Therefore, the basis of the VOD principle is the energy efficiency of mine ventilation systems under the condition of sufficient ventilation for all work areas. It is impossible to ventilate all areas of the mine simultaneously; this would result in an extremely large amount of funds to meet all the requirements of the safety standard and could make the venture unfeasible.

The increase in diesel consumption due to longer transport distances, as the depth of the mine advances, contributes to the increase in the expenses with ventilation because more equipment will be necessary and, consequently, more gases will be emitted. Renewable energy alternatives can help to solve these problems and prevent the costs spiralling out of control (Davidse, 2015, cited Deloitte, 2015). According to Pinto (2018), the use of electric LHDs proves to be advantageous not only for the well-being of the worker but also reveals that, when well dimensioned, it can drastically reduce the energy consumption of the ventilation system, leading to a $33 \%$ to $60 \%$ decrease in ventilation costs.

As a result of this scenario, the Brazilian mines saw the need to seek modern solutions to the problems presented. Only after 13 years from the appearance of the technique, the Ipueira Mine (Bahia) has become the pioneer of this application in Brazil.

\section{Methodology}

This article aims to discuss technical, cost and safety aspects of underground mine ventilation. A detailed survey of current practices and discussions with miners (technical visits and interviews), complemented by literature review, was carried out to identify pertinent problems and existing techniques to minimize ventilation costs.

\section{Case studies}

A description of some deployments applied in Brazilian and foreign mines to show the application and results of VOD technique is necessary

\subsection{Lamego Mine - Anglo Gold Ashanti}

The ventilation system of this mine has a system capable of remotely enabling and disabling each of the 23 fans installed in the mine. They are used to make the permanent renovation of the air in the mine at a depth of up to $600 \mathrm{~m}$. The ability to turn on and off the devices individually has led to a savings of about $\mathrm{R} \$ 40,000$ monthly (since May/2013) according to
Moraes (2014). The mine has an energy restriction, so the energy consumption must be well controlled and optimised. Measures adopted involved the installation of a control room to monitor the ventilation of the mine. Some of the fans are turned off during shift changes and when there is no mine operation. The primary mine ventilation plan was optimized with for theverification of the efficiency of the method.

the installation of ventilation systems "booster", involving several standard small auxiliary fans in parallel, thereby reducing the total pressure to be overcome by the primary fan. In the right environments, pressurizing systems can allow the fresh air needed to be supplied over long distances, thus avoiding the need to replace existing main fans with more powerful units. 


\subsection{Córrego do Sítio I Mine (CDS I) - Anglo Gold Ashanti}

At the moment, the alternative related to demand-side ventilation in the main system is the use of the frequency inverter to modulate the air flow according to the operational needs; in other words, to vary the rotation of the fan according to the distribution of equipment in the mine. In secondary ventilation, the auxiliary fans are switched off during the front shift changes without explosive blasting.

The main ventilation currently has available operating power (energy consumption at the end of the motor shaft) of $12 \mathrm{GWh} /$ year. The estimated annual consumption of primary ventilation with VOD is $6.4 \mathrm{GWh} /$ year. The main ventilation hoods currently operate with an average rotation of $70 \%$ during shifts and $50 \%$ in shift changes. This measurement generates an economy of $53 \%$ in relation to the available operating power.

In auxiliary ventilation, the fans have programmed (time relay) shutdown devices. The time relays turn off the auxiliary fans in shift changes and are only turned back on after the return of the activities. The service front ventilators, programmed to blasting with explosives, are connected to carry out the aeration of the productive gallery at the time of blasting, remaining connected during the shift changes, avoiding impacts for the safety of the employees and for resuming activities.

The auxiliary ventilation has an average installed operating power of $19 \mathrm{GW} /$ year which is approximately twice the power of the main ventilation. With the implementation of programmed shutdowns in the shift intervals using the time relay, the energy consumption of the budgeted auxiliary ventilation has been reduced to $15 \mathrm{GWh} /$ year, representing $21 \%$ of the energy consumption of the auxiliary ventilation.

\subsection{Cuiabá Mine - Anglo Gold Ashanti}

The mine has 35 fans in operation per frequency inverter. In 2019, 70 fans should be in operation. These fans are controlled through a wireless network (Wi-Fi) using the demand for ventilation concepts through a control center. The control of the airflow in the areas required to be ventilated is done by means of sensors scattered in the mine. The use of cameras in strategic locations allows to monitor the doors, avoiding them to stay open without necessity, in addition to seeing possible damage. The ventilation is responsible for $44 \%$ of the electric energy consumed.

Machado (2011) mentions that in 1996, before production increased, mass balance of the ventilation showed the need to equip the mine with two new shafts for adduction and exhaustion to cope with the increase in air flow. These two shafts were projected with a diameter $5 \mathrm{~m}$ and $4.8 \mathrm{~m}$, respectively. The computational modeling

\subsection{Vazante Mine - Nexa}

The mine system has 12 main or surface fans with a power of $250 \mathrm{CV}$, and inside the mine, there are a total of 38 auxiliary fans, with a power of $125 \mathrm{CV}$, that serve to make the distribution of air inside the mine. These fans were connected all the time, which demanded a large amount of energy, and generated a high cost for the company, in the order of $\mathrm{R} \$ 7,900,473$ (US\$ 2,079,072) per year, of which $\mathrm{R} \$ 3,058,248$ (US\$ 804,802) with the main or surface fans, and $\mathrm{R} \$ 4,842,225$ (US\$ $1,274,270$ ) spent on the internal fans, considering only 7,008 hours since the maintenance time of these fans is already discarded.

The proposal is to turn off the fans showed their best positioning. With a length of $780 \mathrm{~m}$, they were dug through modern drilling techniques, using drilling by $R B M$ - type shafts from the surface up to level 11 of the mine.

The first shaft was equipped with an exhaust ventilation system, consisting of three centrifugal fans, each with nominal capacity of $133 \mathrm{~m}^{3} / \mathrm{s}$, pressure of $6.6 \mathrm{kPa}$ and electric motors of 1,200 kW power. The system operates in parallel and the fans are equipped with frequency inverters. This allows the adjustment of pressure and flow.

The Cuiabá mine is equipped with a supervisory system, which controls and monitors the main hoods located on the surface. The system receives the information about the flow and static pressure of the fans, vibration levels and temperature, electric current, together with the voltage and rotation of the motors, indicating the

in shift changes so that there is thus a reduction in energy costs of ventilation. This project, which is being adopted, spends a total of R \$ 2.3 million (US\$ 605,263), and is divided into two parts: in the first, a total of R\$ 1.4 million (US\$ 368,421); in the second, $\mathrm{R} \$ 900$ thousand (US\$236,842) to keep it running. Through testing, it has been proven that with the adequacy of the mine, there will be a great saving for the company.

In the tests done in the ventilation system, turning off the fans, as long as possible, without it affecting the air quality, there will be a savings of $\mathrm{R} \$$ 1,236,891 (US\$ 325,497) during the year. Due to the fact that the price of the frequency inverter has reduced dramatically, it has been possible to shut down state of the hoods. The system is equipped with power consumption, which consists of controlling the speed of rotation of the exhaust systems at specified times in accordance with the situation of the mine.

Trucks unload the ore into the ROM silo of the primary crushing plant, located near the vertical shaft at level 11 of the mine. The ore, once crushed, is hoisted to the surface through the vertical shaft and shipped by belt conveyors to the beneficiation plant. The diesel fleet utilization factor plays a crucial role in determining the required volume of air as well as the rate of heat it discards in the ventilation system, with significant impacts on the required airflow. Another alternative is the use of electric loaders and jumbos. The first equipment (diesel) requires an amount of air to dilute the gases, in addition to being a larger heat exchanger that overloads the ventilation system.

or reduce the speed of the fans (their rotation will decrease), thus requiring less energy. In less than 2 years, the investment of R\$2.3 million will be paid for with the reduction of energy (Maciel, 2015).

The energy expenditure with main ventilation represents about $7 \%$ of the whole unit and $40 \%$ of the mine's consumption. The system has level 3 of VOD, which means that the speed of the fans can be controlled manually or through the control room dispatch. Schedules can be created based on time of entry and exit at the mine, period of detonation and aeration. With the implementation of the project, a reduction of approximately $15 \%$ should be achieved (Pereira, 2018). 


\section{Results and discussion}

Most mine ventilation systems are inefficiently designed, being more focused on facilitating production flexibility than minimizing energy consumption. The energy consumption of a mine, according to several authors from different mining countries can reach up to $60 \%$ of the total energy consumed underground.

The ventilation on demand system (VOD), as evaluated in some Canadian mines, is targeting the operation of auxiliary ventilators that ventilate each work site where mining activity occurs, according Hardcastle et al. (2005). In Brazil, in the mines studied, ventilation on demand is basically concentrated in the main ventilation system, using frequency inverters, as shown in Pereira (2018). Other alternatives are pointed out by Costa (2017) as power off auxiliary fans during shift changes, sizing production in periods where the cost of energy is cheaper. Maintenance and proper installation of ducts allowed the Ipueira Mine-BA to have a significant cost savings on ventilation. The author suggests replacing the smaller ducts with large ducts to reduce the resistance of the ventilation circuit, widening of chimneys, and communication between levels or between galleries of the same level, which are measures that must be also analyzed.

Table 1 presents a summary of the mines mentioned in the text, highlighting the yearly economic savings registered by them and the practices that led to the desired results.

Table 1 - Summary of ventilation information of the Brazilian mines cited.

\begin{tabular}{l|c|c|c|c}
\hline Characteristic & Córrego do Sítio I Mine & Cuiabá Mine & Lamego Mine & Vazante Mine \\
\hline $\begin{array}{l}\text { Number of fans } \\
\text { (main and auxiliary system) }\end{array}$ & \multicolumn{2}{|c}{25} & 35 & \multicolumn{2}{c}{50} \\
\hline Ore & Gold & Gold & Gold & Zinc \\
\hline Current Depth (m) & 800 & 1.400 & 400 & 850 \\
\hline Location & Santa Bárbara-MG & Sabará-MG & Sabará-MG & Vazante- MG \\
\hline Mining methods & $\begin{array}{c}\text { Cut and Fill (backfill) } \\
\text { and Sublevel Stoping }\end{array}$ & $\begin{array}{c}\text { Cut and Fill; hybrid; } \\
\text { Room and Pillar }\end{array}$ & Sublevel Stoping & Sublevel Stoping \\
\hline Flow rate (m) $/ \mathbf{s})$ & 440 & 400 to 720 & 500 & 500 \\
\hline Annual savings $(\%)$ & 21 & 25 & - & 15 \\
\hline
\end{tabular}

CPEC (2005) describe the operations that consume the most electricity in relation to ventilation in several Canadian mines (Table 2). Ventilation is the largest consumer, responsible for $34 \%$ of all the energy spent in the mine. In the year (2018), the cost of energy in Brazil has increased due to the water crisis $(95 \%$ of the electric energy is generated by hydroelectric plants). The reservoirs were at very low levels and it was necessary to increase the utilization of the thermoelectric plants, which caused the increase in energy costs (red flag). As ventilation is one of the largest consumers, stricter control measures are necessary.

Table 2 - Energy costs in Canada (modified from CPEC, 2005) - \$/tonne.

\begin{tabular}{l|c|c|c|c|c|c}
\hline \multicolumn{1}{c|}{ Operation/ Unit Costs } & Minimum & Maximum & Medium & \multicolumn{1}{c|}{$\begin{array}{c}\text { Ventilation } \\
\text { Relative }\end{array}$} & \multicolumn{2}{c}{$\begin{array}{c}\text { Total } \\
\text { Relative }\end{array}$} \\
\hline Drilling & 0.13 & \multicolumn{2}{|c|}{0.72} & 0.43 & \multicolumn{2}{c}{$21 \%$} \\
\hline Blasting & 0.21 & 3.23 & 1.72 & $85 \%$ & $29 \%$ \\
\hline Mucking & 0.11 & 0.33 & 0.22 & $11 \%$ & $4 \%$ \\
\hline Underground Ore transport & 0.01 & 0.25 & 0.13 & $6 \%$ & $2 \%$ \\
\hline Underground Crushing & 0.01 & 0.08 & 0.05 & $2 \%$ & $1 \%$ \\
\hline Hoisting & 0.1 & 0.64 & 0.37 & $18 \%$ & $6 \%$ \\
\hline Ore Transport to Mill & 0.01 & 0.64 & 0.33 & $16 \%$ & $6 \%$ \\
\hline Ventilation & 1.11 & 2.92 & 2.02 & - & $34 \%$ \\
\hline Backfill & 0.03 & 0.35 & 0.19 & $9 \%$ & $3 \%$ \\
\hline Dewatering & 0.09 & 0.42 & 0.26 & $13 \%$ & $4 \%$ \\
\hline Other Underground Support & 0.05 & 0.35 & 0.20 & $10 \%$ & $3 \%$ \\
\hline
\end{tabular}

Reducing the energy of the main ventilation system is highly dependent on the rate of primary air fan flow capacity and power of the diesel equipment used underground. The ability to change the fan airflows throughout the mine to provide the volume of air to where it is needed is another important characteristic.

The fans are designed to deliver the maximum demand of the system in which they are installed. Often the actual demand varies and may be much lower than the design capability. The fans typically show a number of curves for different fan speeds, including the efficiency and power required. 
These graphs are very useful in choosing the ideal fan for any application and they are necessary to predict the operational parameters when the operational condition is changed.

As the fan power is proportional to the cube of the airflow, then a possible $20 \%$ reduction in the airflow allows savings of about $50 \%$ of the energy required to operate the fan. The ventilation is mainly dimensioned according to the minimum flow required for diesel equipment, varying between 0.05 and $0.06 \mathrm{~m}^{3} / \mathrm{s}$ per $\mathrm{kW}$. In addition, a minimum air velocity (usually $0.5 \mathrm{~m} / \mathrm{s}$ ) must be maintained in all areas, according to Brasil (1999).

Establishing a comparison between the Brazilian and foreign mines, it is observed that the demand ventilation in the foreign mines presents a deeper level cost control. Brazil is joining the changes recently with many significant results, but

\section{Conclusions}

The study shows that ventilation has become a priority for the world and Brazilian mines in relation to the economic, safety and environmental issues. There were many accidents in the past related directly or indirectly to this issue. Precarious ventilation increases the likelihood of accidents, illness and low productivity. Therefore, adequate ventilation is fundamental for both safety and the economics of underground mining.

Among the Brazilian mines, two have installed a high level of ventilation on demand as a more advanced cost control tool. Only Cuiaba and Ipueira mines feature modern control room monitoring of fans, and the use of sensors in some of the mine points to control the flow and gases in an automated fashion. Corrego do Sitio I and Lamego mines use the simplest form of this technique.

Various tools provide satisfactory results, and essential use of automation for monitoring the airflow, speed settings of the fans, their distance from each other or their scheduling in the shift change. due to the need for high investments in automation and system programming, demand for ventilation is in the inicial stages in the studied mines. Most of the Brazilian underground mines do not have ventilation on demand. Optimization in ventilation systems is not commonly conducted. Existing systems remain unchanged and are only supplemented with additional volumes as new sections are developed, resulting in a general loss of efficiency.

The economic feasibility analysis of the implementation of the VOD system for auxiliary fans is also a point to be analyzed, as studies show, in some mines, being the largest consumer of electricity. To do this, it is necessary to install more flow regulators in the ventilation chimneys and in the accesses to the levels, to ensure the proper air directioning.

Most suitable adjustment in equipment installation ("setup"), as realized in the Taquari Vassouras Mine-Sergipe, provides saving features for ventilation (Moura, 2013). Those would remain in strategic places in the return gallery without the need for displacement, whereas only the ducts would be prolonged, therefore reducing the need for loaders (LHDs) in the mining panels for the material transportation.

The use of electric trucks and LHDs is an alternative to relieve the ventilation system. The use of diesel fuel in underground mines makes the environment warmer, more polluted, and implies greater financial cost with ventilation to dilute toxic gases. The use of electrical LHDs can reduce by $33 \%$ to $60 \%$ (Santomauro, 2017) the energy consumption of the ventilation system. Ventilation costs will still remain higher, but the cost of electric LHDs compared to diesel LHDs will decrease (Jacobs et al., 2015).
The introduction of electrical equipment generating less heat requiring less airflow. However, the high cost of buying equipment hampers their effective deployment in Brazilian mines, and have a lower efficiency compared to diesel equipment. The studies show that the reduction of energy consumption in the main ventilation system will depend, mainly, on the power of the diesel equipment operating underground.

Among the reported practices used in Brazil, VOD includes the shutdown and (or) reduction of the fan speed (through frequency inverters) during shift changes, remote fan control and installation of flow control sensors (Cuiabá and Ipueira Mines). Frequency inverters (speed drivers) provide additional advantages, such as the ability to control the motor speed of any fan in operation. This will be very advantageous when one fan needs to be started while the other fans are already in operation.

The use of VOD does not only lead to a reduction in energy consumption but can also be used to increase production or expand the mine network with the available ventilation utilities. The adjustment should tailor the use of the equipment, if for example a loader does not work at the maximum capacity, emissions are reduced by providing the central location information, characteristics of the equipment and its operational performance data, whereby the air adjustments can be made posteriorly. These procedures are responsible for saving thousands of dollars annually.

As observed in Table 2, ventilation is one of the largest consumers of electric energy, so it is important to monitor and study cost control techniques.

Application of softwares such as VENTSIM, widely used in most of the world's mines, allows a more efficient control of the ventilation circuit, reducing its resistance and allowing a correct dimensioning of the amount of air required.

Reliable ventilation is vital to the health and safety of miners, to ensure that particulate matter and toxic gases from diesel engines be adequately diluted.

\section{References}

BRASIL. Ministério do Trabalho e Emprego (MTE). NR 22 - Segurança e Saúde Ocupacional na Mineração. Brasília, DF: Ministério do Trabalho, 1999.

COSTA, J. C. A. Estudos para Implantação de um modelo de ventilação sob demanda no complexo mineiro de Ipueira - Ferbasa, município de Andorinha - Babia. 2017. 95 f. Tese (Doutorado em Engenharia de Processos) Universidade Federal de Campina Grande, Campina Grande, 2017.

COSTA, L.V. Análise via simulação da ventilação em mina subterrânea: estudo de caso mina Córrego do Sitio I. 2019. 117 f. Tese (Doutorado em Engenharia Mineral) - Escola de Minas, Universidade Federal de Ouro Preto, 2019. 
CPEC. Benchmarking the economic costs of canadian underground bulk mines. [S. l.]: CANMET, 2005. p.19-49. DE SOUZA, E. Cost saving strategies in mine ventilation. CIM Journal, v. 9, n.2, 2018.

DELOITTE. As tendências da mineração: as dez principais questões que as empresas do setor enfrentarão em 2018. Available at: https://www2.deloitte.com/content/dam/Deloitte/br/Documents/energyresources/TendenciasMineracao2015.pdf. Accessed: 23 Nov. 2018.

HARDCASTLE, S. G.; KOCSIS, C.; BISSIRI, Y.; BAIDEN, G. Optimizing mine ventilation through the use of life-cycle production models. In: INTERNATIONAL MINE VENTILATION CONGRESS, 8., 2005, Brisbane, Australia. Proceedings [...]. Melbourne: Ed. A.D.S Gillies, AUSIMM, 2005. p. 373-361

JACOBS, W., HODKIEWICZ, M. R. A cost-benefit analysis of electric loaders to reduce diesel emissions in underground hard rock mines. IEEE Transactions on Industry Applications, v. 51, n. 3, p. 2565-2573, May/June 2015.

KOCSIS, C. New ventilation design criteria for underground metal mines based upon the life-cycle airflow demand schedule. Ph.D. Thesis, University of British Columbia, Faculty of Graduate Studies, Department of Mining Engineering, Vancouver, BC, Canada., p.10-11, 2009.

MACHADO, H. G. Gestão de Riscos em Minas Subterrâneas - Avaliação de minas subterrâneas profundas. Dissertação de Mestrado. NUGEO. UFOP. 2011.

MACIEL, W. Implantação da ventilação sob demanda em mina subterrânea do Noroeste de Minas Gerais. Faculdade do Noroeste de Minas Gerais. Monografia de Graduação. Paracatu. 2015.

MOURA, V.B. Novos modos operantes no sistema de exaustão das frentes de Lavra da mina Taquari Vassouras. Monografia de Especialização. Universidade Federal de Ouro Preto. Escola de Minas. 2013.

MORAES, T. A mina de ouro subterrânea da AngloGold em Sabará. Jornal Hoje em dia, 15 jun. 2014. Available at: https://www.hojeemdia.com.br/primeiro-plano/economia/. Accessed: 15 Nov. 2018.

PARASZCZAK, J.; SVEDLUND, E.; FYTAS, K.; LAFLAMME, M. Electrification of loaders and trucks: a step towards more sustainable underground mining. Renewable Energies and Power Quality Journal (RE\&PQJ), v. 1, n.12, p. 81-86, Apr. 2014.

PEREIRA, F.C. Implementação do sistema de ventilação sob Demanda na Mina Vazante. Monografia de Graduação. Universidade Federal de Ouro Preto. 2018.

PINTO, T.A.M. Consequências do Uso de Carregadeiras Tipo LHD Elétricas em Minas Subterrâneas. Monografia de Graduação. Universidade Federal de Ouro Preto. 2018.

RAMJACK. How ventilation on demand (VOD) can reduce mine operating costs. RAMJACK Technology Solutions, 6 Oct. 2015. Available at: https://ramjack.co.za/mining-resources-articles/ventilation-demand-vod-reduce-operating-costs/. Accessed: 13 Jan. 2019.

SANTOMAURO, A. Liberdade de movimento. Revista Manutenção e Tecnologia, 13 out. 2017. Available at: http://www.revistamt.com.br. Accessed: 14 Jan. 2019.

Received: 26 April 2019 - Accepted: 12 April 2020. 